\title{
Stakeholder participation in CDM and new climate mitigation mechanisms: China CDM
} case study

\section{Dong, Yan; Olsen, Karen Holm}

Published in:
Climate Policy

Link to article, DOI:

10.1080/14693062.2015.1070257

Publication date:

2017

Document Version

Peer reviewed version

Link back to DTU Orbit

Citation (APA):

Dong, Y., \& Olsen, K. H. (2017). Stakeholder participation in CDM and new climate mitigation mechanisms: China CDM case study. Climate Policy, 17(2), 171-188. https://doi.org/10.1080/14693062.2015.1070257

\section{General rights}

Copyright and moral rights for the publications made accessible in the public portal are retained by the authors and/or other copyright owners and it is a condition of accessing publications that users recognise and abide by the legal requirements associated with these rights.

- Users may download and print one copy of any publication from the public portal for the purpose of private study or research.

- You may not further distribute the material or use it for any profit-making activity or commercial gain

- You may freely distribute the URL identifying the publication in the public portal 
Yan Dong \& Karen Holm Olsen (2015): Stakeholder participation in CDM and new climate mitigation mechanisms: China CDM case study, Climate Policy, DOI: 10.1080/14693062.2015.1070257

\section{Stakeholder participation in CDM and new climate mitigation mechanisms - China CDM case study}

\section{Introduction}

Public participation is recognized as a key principle for effective climate governance in Article 6 of the United Nations Framework Convention on Climate Change (UNFCCC, 1992). In various international environmental agreements (Agenda 21, the Rio Declaration on Environment and Development, and the Aarhus Convention), stakeholder participation is also recognized as a right and a means to ensure good governance, transparency, integrity, and sustainable development, as well as to prevent human rights violations. While rules exist on global and local stakeholder consultations, these rules are vague and there are numerous cases in which local communities have not been adequately consulted. For example, the Bajo Aguan biogas Clean Development Mechanisms (CDM) project in Honduras and the Olkaria geothermal power plant CDM project in Kenya both suffered from land occupation issues not being handled appropriately (Schade and Obergassel, 2014). Similarly, Santa Rita hydroelectric dam CDM project in Guatemala failed to properly consult local indigenous people, who were strongly affected by the project (Theguadian, 2014). In all the three cases, extreme situations appear, including people being killed and houses being burned as the consequences of conflict between local communities and the project developer. Evidently, the Local Stakeholder Consultation (LSC) process in CDM was not carried out with success in these cases, where the issues potentially could have been alleviated through a proper LSC process. This is largely due to lack of clear guidance to project participants and independent validators regarding whom to consult, when, by what method, and how to properly respond to local stakeholders comments (CDM EB, 2012). Responding to this critique, Parties to the Kyoto Protocol requested the CDM Board (UNFCCC, 2013) to collaborate with the Designated National Authority (DNA) Forum to provide information on LSC practices and to provide technical assistance to DNAs upon their request for the development of guidelines for LSC in their countries. 
Unlike the CDM, new climate mitigation mechanisms have more stringent stakeholder participation rules in place. The UN-REDD Programme and Forest Carbon Partnership Facility have prepared joint guidelines on stakeholder engagement in REDD+ Readiness, which include mechanisms for grievance, conflict resolution, and redress (FCP, 2012). The REDD+ framework provides a useful set of established international safeguards, including effective means to access justice as a necessary component of implementing safeguards. Also, the Green Climate Fund's accreditation process addresses environmental and social safeguards by examining environmental and social indicators and applying rating and scoring systems. It also includes a grievance mechanism and mandatory reporting on co-benefits (GCF, 2014a, 2014b). These new mitigation mechanisms have only been in operation for a short time, thus the effects of the improved LSC guidelines in practice are not yet clear. Although the CDM has been in action for a much longer time, little empirical research exists on how the principles of LSC are practiced and synergies between experiences with REDD+, the GCF, and implementation of Article 6 of the UNFCCC are largely unexplored.

Inspired by Rowe and Frewer's evaluation framework of public participation methods (Rowe and Fewer, 2000), the study explores, how international rules for LSC are practiced at national and local levels in the case of a non-controversial CDM project in China. The aim of the study is to contribute with new knowledge and insights to better shape future LSC in climate mechanisms, learning from strengths and weakness of existing LSC guidelines and practices in CDM, especially focusing on the weakness of relevant regulations in current climate mechanism policies. Therefore, we first examine the relevant rules on LSC in CDM and guidelines developed in new mitigation mechanisms. Next, a number of Project Design Documents (PDDs) are reviewed, where LSCs are described in detail and reported to Executive Board (EB). A small scale CDM run-of-river hydropower project is explored to further understand, how international LSC rules in the CDM are translated into national LSC policies and are implemented in practice in the case of China. The strengths and weaknesses of the CDM LSC rules and practices are discussed to identify opportunities for strengthening the LSC process in the context of exploring synergies with new mitigation mechanisms to increase participation, transparency and effective decision-making. 


\section{Comparison of Rules on Local Stakeholder Participation in the CDM with Rules and Guidelines in New Mitigation Mechanisms}

$\mathrm{CDM}$ rules determine the requirement for the consultation of local stakeholders on the impacts of a CDM project in the area in which it will be developed. The process must be conducted and documented by project participants as a precondition for project validation. CDM Modalities and Procedures determine two consultation processes during validation: LSC required at the project design stage, and global stakeholder consultation (GSC), taking place at the validation stage (CDM EB, 2011b).

Ahead of the preparation of the PDD, the project developer must consult local stakeholders that are potentially affected by the proposed CDM project activity. However, the rules fail to specify whom exactly to consult and in what way. It is therefore largely left to the host country to define rules on LSC, which often include a set of non-binding guidelines (Schade and Obergassel, 2014). The project developer is obliged to respond to stakeholders' comments and show how they have been taken into consideration and properly addressed. The outcomes of the stakeholder consultation must be documented in the PDD (CDM EB, 2011b), but this is often perfunctory and badly regulated.

After the PDD is finalized, it must be made publicly available on the UNFCCC CDM website for a period of 30 days (45 days for Afforestation/Reforestation projects). During this validation period, Parties, stakeholders and UNFCCC accredited observers can submit comments through the process of the global stakeholder consultation. Designated Operational Entities (DOEs), which are hired as independent third-party validators, need to confirm by means of document review and interviews with local stakeholders that relevant stakeholders have been consulted through appropriate means and that comments from local stakeholders have been appropriately taken into account and included in the PDD. Yet, what is appropriate is left for the DOEs to decide (CDM EB, 2011b).

Nevertheless, the CDM rules for stakeholder consultations are quite general and are poorly defined, regulated and documented. This is mostly due to the lack of clear guidance provided by the CDM Board on how to organize, structure and carry out a local stakeholder consultation. Due to missing internationally agreed procedures for conducting local stakeholder consultations, project developers have to determine their own methods (Johl and Lador, 2012). Some countries 
have stricter rules on consulting local stakeholders in order to obtain a construction license or the approval of the Environmental Impact Assessment (EIA). However, it is unclear how the international CDM rules and the national rules on local stakeholder consultation relate to each other (Carbon Market Watch, 2014).

The need to improve LSC in the CDM project cycle has been expressed in a number of submissions by a range of stakeholders (e.g. Project Developer Forum, non-governmental and civil society organizations, Designated Operational Entities, Independent Entities Association, and private individuals) (CDM EB, 2011a). Based on the inputs received from the calls and interaction with stakeholders at CDM round tables, the CDM Board at its eighty-first Board meeting in November 2014 decided on a new validation and verification standard and CDM project cycle procedure, which entered into force on 1 April 2015.

The new rules inter alia determine that LSC are to be conducted in accordance with applicable national regulations, if any.' In the light of different and often poor national rules in place, central power will still lay in the hands of the host country to determine what is necessary. Upcoming validation requirements also govern that if significant changes occur in project design after the initial LSC, the DOE shall assess whether the engaged stakeholders and their comments are still valid. Furthermore, currently stakeholders have no means to channel complaints after the consultations have been conducted. The new rules designate that after the LSC and in the course of validation, DNAs shall forward any complaints received by local stakeholders to the DOEs. The DOE shall then submit them to the project participants or the coordinating/managing entity and determine whether complaints have been properly considered (CDM EB, 2011b). However, whether or not a stakeholder can appeal against decisions of the Board regarding registration or rejection of the project is still under negotiations.

The CDM Board indicated that more details on how a local stakeholder consultation has to be conducted are to be further specified. During the course of 2015 elements such as which stakeholders to consult, by what means and how to address stakeholder comments received after registration of a project activity are to be considered in future Board meetings. Nevertheless, $\mathrm{CDM}$ is still considered as lagging behind the new climate mechanisms in providing an effective remedy for affected stakeholders. In comparison, the UN-REDD Programme jointly with the Forest Carbon Partnership Facility prepared guidelines on stakeholder engagement in REDD+ 
Readiness to ensure that actions uphold the rights of stakeholders and that indigenous people are meaningfully involved in decision-making processes.

Activities affecting indigenous peoples are governed by the World Bank Operational Policies. In the Readiness Preparation Proposal, guidelines and requirements on LSC are described in detail, including 'define the desired outcomes of the consultation; identify stakeholders, identify the issues to consult on; define the terms of the consultation; select the consultation and outreach methods; ensure that stakeholders have sufficient capacity to engage fully and effectively in consultations; conduct the consultation; analyze and disseminate results' (FCP, 2012). It is ahead of the CDM by determining an impartial, accessible and fair mechanism for grievance, conflict resolution and redress during the consultation process and throughout the implementation. Still, limited advice is provided on the operationalization, what to include in the mandatory Safeguard Information System and on how to engage local communities in data collection and monitoring (FCP, 2011). Numerous rules mandate public participation in both the CDM and REDD+ mechanisms, but experience shows that there is a gap in operationalizing the requirements, and synergies between the two mechanisms remain unexplored. By sharing experience and good practice such mechanisms could inform further rules on LSC.

A grievance mechanism is included in a number of other operating entities of the UNFCCC, such as in the operational guidelines of the Green Climate Fund. The fund defines an environmental and social management system and foresees extensive stakeholder participation in the design, development, and implementation stages (GCF, 2014a).

The focus on the importance of LSC in climate actions is already grounded in UNFCCC, specifically in Article 6. As a step to address this, Parties to the Kyoto Protocol adopted the Warsaw decision 3/CMP.9 (UNFCCC 2013), which requests the CDM Board to work with DNAs to provide technical assistance and develop guidelines for LSC in countries that request assistance. Together with political pressure to reform other mechanisms, such as REDD+, this provides a good opportunity to build on existing best practice guidelines and to strengthen and clarify the requirements for stakeholder involvement and grievance mechanisms in the lead up to COP 21. 


\section{Methods and Materials}

To examine how international CDM LSC rules are integrated with national rules and implemented in practice, China was investigated as a case study. The case methodology consists of: (1) An assessment of CDM policies in China; (2) Analysis of 109 small scale run-of-river hydropower (SSRRHP) PDDs describing, how LSC was carried out and documented in projects that were registered before April 2010; (3) Investigation of the Liyutang SSRRHP CDM project to demonstrate, how LSC is conducted in practice, mapping key stakeholders, assessing stakeholder participation approaches and identifying strengths and weaknesses of the process.

An evaluation guideline for the assessment of the stakeholder participation processes was developed as shown in Table S1 in appendices, inspired by the widely used evaluation criteria developed by Rowe and Frewer (2000). Similar examples using the same criteria can be found in Lamers et al. (2010), Zorrilla et al., (2009), Rowe et al., (2001), etc. Their criteria were to assess LSC with an aim to include the public in policy making. We adapted the criteria to suite the purpose of this study by taking the public's opinion into decision making at the project level (Table S1 in appendices).

The CDM policies were analyzed through coding according to the guidelines in Table S1 in appendices. If text related to indicators in Table S1, it was coded with the relevant indicators. 109 SSRRHP PDDs were analyzed to get an overview of the stakeholder participation situation. Therefore, the stakeholder participation section in each PDD was evaluated according to the guidelines developed in Table S1. The results are summarized in section 4.3.The results reveal, how the rules and goals of stakeholder participation in CDM policies are implemented in SSRRHP by means of documentation.

A single case of the Liyutang CDM hydropower project in Chongqing was conducted to obtain and display ground realities. For feasibility reasons, existing contacts of the authors were used first to get in contact with some of the stakeholders. Then a snowball sampling method was used to trace additional stakeholders. In addition to a field visit of the project site, 11 interviews were conducted in Chongqing and Beijing, China (Table S2 in Appendices). Interviews were conducted in Mandarin. Note that due to feasibility reasons, some of the interviewees are not directly related to the specific case study but were people who hold similar positions in similar projects. Most of the interviewees preferred not to be referenced publically and therefore all of 
the contributors are kept anonymous. The insecurity of the interviewees may lead to a bias in favor of safe information instead of critical comments. Another limitation of this study is that it was not feasible to follow a project for several years. This study took place in 2009-2010, which was four years after the PDD was approved by China's government and two years after the project was registered with the CDM Executive Board (EB). At that time the majority of project construction had finished and the interviews thus reflect stakeholders' opinions at this specific point in time.

\section{Case Study of Local Stakeholder Consultations in CDM in China}

\section{1. Background on Stakeholder Participation in China}

Any attempt to analyze stakeholder participation needs to begin with an understanding of the complexity of China's social problems, and the unique historical, cultural, and practical barriers to public participation. While Western countries focus on the role of individuals in society, the idea that the individual is subordinate to the interest of the state is still present in China (Berry et al., 1997). The Chinese public is used to top-down decision-making procedures and considers this as the best way to treat national affairs (Martinsons and Davison, 2007; Lieberthal and lampton, 1992). Only limited public participation is implemented in China, mainly due to the assumption that the public lacks the knowledge and capacity to participate in decision making. Given the fact that experts are usually believed to have the best professional and technical knowledge, an expert-oriented approach in China remains mainstream when making plans (Li et al., 2008). Moreover, Buckley (2007) pointed out that locals do not dare to 'say something'. This can be reflected in many old Chinese parables, such as 'The first bird which flies out will be shot first' from the Ming dynasty'; 'The biggest trees suffer the wind most'; 'The fattest pig is butchered first' etc. These parables are treated as the precious wisdom of Chinese ancestors, and are deeply rooted in many Chinese people's minds.

The right of the Chinese people to participate in public affairs is written in the constitution, as well as in other legislation. However, these laws have the same failure in common: the lack of operational and procedural details (Hong \& Luan, 1999). Another reason for poor stakeholder participation is the lack of active NGOs in public life. Gu and Sheatehas (2005) pointed out that NGOs are controversial in China. Due to different understandings of NGOs and blurred government attitude, there is still a long way to go for NGOs to act as their overseas counterparts. 
This background indicates that significant barriers against effective stakeholder participation exist in China.

\subsection{Stakeholder Participation Policies in China}

Two procedures must be followed to implement a CDM project in China. One is to comply with the CDM application and implementation regulations published by the Chinese government: 'Measures for the operation and management of CDM projects in China' (Government of the PRC, 2005). This document does not contain requirements on stakeholder participation. The other procedure is to implement the project under the existing project implementation framework as a normal project, regardless of whether it is a CDM project or not. Here several permissions, plans, and applications are needed for the approval of project implementation. We only focus on the policy documentation involving stakeholder participation. According to the 'Construction project Environmental Impact Assessment categorized management catalogue', an EIA is one of the procedures that all projects involving construction need to comply with (MEPPRC, 2008). Stakeholder participation is a mandatory requirement and should follow 'Provisional measure for EIA public participation' (referred as EIAPP) (Government of the PRC, 2006), which is the first and probably the only national formal document in China including detailed requirements on public participation. This document provides a good guidance for stakeholder participation, including proposals on choosing stakeholders representatively, introducing tasks clearly, explaining expected discussion issues to the public, etc. The document also describes and recommends several stakeholder participation mechanisms with guidelines, including surveys, expert consultations, symposia, argumentation meetings, and public hearings. Transparency is highly demanded but how much public opinion should be taken into consideration is not clearly identified.

\subsection{LSC Practices in Small-Scale Run-of-River Hydropower Projects}

We examined 109 SSRRH PDDs to get an overview of documented LSC practices. In the stakeholders' comments section in PDDs, nine projects explained that LSC activities carried out during EIA is part of the context in stakeholders' comments. Seven projects said that in addition to LSC conducted during the EIA, they also conducted extra LSC for the purpose of CDM application. The other 93 projects have not clarified if their LSCs were only conducted during EIA, or if additional LSC activities were conducted for CDM application. This leads to our first 
doubt: Is LSC taking place during EIA or CDM application? The low rate of discussions on CDM project design and greenhouse gas reduction further raises doubts.

\section{Table 1: Evaluation Results of Stakeholder Participation in Small-Scale Hydropower CDM Projects}

A wide range of stakeholders were consulted, including local residents, local government, project employees, experts, social organizations, enterprises, a power company and a bank. More than half of the projects conduct LSC more than once. Thus more than one participation mechanism can be used in one project. Following the recommendations in China's EIA, a survey is the most preferred way to incorporate public participation (Table 1), as it is considered to be the most accessible and cost-efficient way (Rowe and Frewer 2000). Though a consultation meeting is considered more effective for reaching meaningful results, which may be further integrated into decision-making (Rowe and Frewer 2000), it is used in less than half of the projects. Generally the tasks of stakeholder participation are well explained to the stakeholders. But with a lack of requirements in policies, early involvement and independence were badly performed (Table 1). The late involvement of CDM stakeholders makes it impossible for them to have any major influence on project plans. Most LSC are conducted by people who were chosen by the project owner. This may lead LSC results in bias towards the project owner. Transparency is another issue. Out of all the projects, only one project invited media to record the process. There are hardly any results published to the public.

The result of stakeholder participation is very interesting. In approximately $12 \%-50 \%$ of projects, local residents had positive comments on increasing employment opportunity, improving infrastructure, income, and energy resources. In a little more than $20 \%$ of projects, local stakeholders had negative concerns regarding compensation, environmental impacts on land, water, noise, and nature conservation. Among those comments, the project owner took stakeholders' negative comments into consideration and actually revised the project in less than $8 \%$ of projects. Thus it is hard to say that stakeholders' comments are well taken into account, both because of the low rate of negative concerns, and the lack of policy to mandate the project owner to take negative comments into consideration.

\subsection{Liyutang CDM Hydropower Project}


To further examine LSC in practice in a concrete case, we investigated the 'Liyutang CDM hydropower project'. It is located in Kai County, Chongqing, China (first level at $108^{\circ} 18^{\prime} 08.7^{\prime \prime} \mathrm{N}$, $31^{\circ} 22^{\prime} 23.5^{\prime \prime} \mathrm{E}$, and second level at $\left.107^{\circ} 55^{\prime} 48^{\prime \prime} \mathrm{N}, 30^{\circ} 49^{\prime} 30^{\prime \prime} \mathrm{E}\right)$. The power station is placed next to Liyutang reservoir, which was built as the irrigation and drinking water reservoir for Kai County, from 2003 to 2008. Both of the two projects are run by Liyutang Company. The power station project activity started in July, 2006 (Ecosecurity Inc. 2008). At the time when the author investigated the project site (2010), the majority of the construction was finished and the power station was stepping into an operation and maintenance period. The application process started in late 2006. It was validated in 2007 and registered in 2008.

Local residents live in small villages about 100 meters above the reservoir. Each village consists of approximately 40 families. They mainly make their living from agriculture, planting in the mountains around the reservoir (interview with local resident, 2010). The hydropower station is built on the reservoir, which was already in the construction phase when the power station was planned. As a result, the local residents who live in the area were already relocated and compensated by the reservoir project. No new migrants were created by the hydropower project.

\section{Stakeholder consultation processes involved in the case study}

As a normal construction project in China, the application of the project followed the hydropower project application procedures. At the beginning of project application, the project owner wrote a formal project plan and sent it to the government for approval. After it was approved, the project owner hired authorized documentation compiling institutions * to investigate and write further detailed application documents. Those documents were sent to the government for approval again. In this process the majority of participatory approaches involved government and expert consultations (interview with private project owner, government officer and public project developer, 2010). Two documents were prepared in cooperation with local residents - namely, project construction land-use and immigration relocation report and EIA. For the first document, local residents were supposed to reach agreements with project owners regarding compensation issues. This is the first and only time that all local residents participated.

\footnotetext{
*Several documents are needed for a project application. These documents can only be compiled by institutions that are authorized by the government.
} 
For most projects, more complicated measures would be undertaken at this stage of the process, including visits and interviews with each local resident separately, several times (interview with private project owner and public project developer, 2010). However, for this specific project, agreement regarding land occupation and compensation issues had already been reached during the reservoir project. In addition, the record of the participatory process is not publicly available. As a result, details of how the first local resident survey was conducted are unclear. The second local resident survey was conducted during the EIA assessment, and was organized by an EIA authorized compiling institution. Similar to the first local resident survey, there is no easily accessible, publicly available record describing the process. However, according to the interviewed project owner and public developer, the consultation at this stage was mostly conducted by questionnaires, which were distributed to relevant stakeholders. These questionnaires were collected after stakeholders had filled out the answers (interview with private project owner and public project developer, 2010). This process was confirmed by local residents (interview with local resident, 2010).

For economic reasons and the unknown project approval result from China's government, the CDM application was not conducted until the last minute, when the project almost had approval results from China's government (interview with PDD consultant and Certified Emission Reduction (CER)-buyer, 2010). As a result, the normal project application procedure was conducted separately before the CDM application process. For many projects, project developers pursue CDM registration to obtain an additional revenue stream from the sales of CERs.

Once the project reached the CDM application process, LSC follows the processes described in section 2. In this specific case, two LSC were held during PDD compiling process. One was a questionnaire survey, in which questionnaires were sent to a sample of local stakeholders, including 60 local residents, 9 local government officers and 5 other undefined stakeholders. The other participatory approach was a comment invitation, where a public announcement was made available in the villages, requesting input or comments from local stakeholders. In general, all participants supported the project. Only one interviewee expressed his/her concern about noise pollution, which will be mitigated by the methods described in the EIA. Due to the overall lack of negative comments, it is hard to tell whether the two stakeholder participation surveys 
conducted for the CDM application add any extra value to the project design. After the PDD was completed, it was sent to China's DNA for approval, where government and expert consultation is used again for the approval process (interview with PDD consultant and China DNA, 2010). Afterwards there were global stakeholder consultation and comments invitation during validation phase.

\section{Participatory approach assessment}

Government and expert consultation was used as the means to get documentation approved by the government, while stakeholder surveys were used to involve local residents. The most important decisions were made through government and expert consultation. This participatory approach is a typical Chinese governmental working procedure. Once documentation is sent to the provincial government, an expert group must be formed for consultation. The experts are chosen by the government from an expert library, which is established by the province-level government. The expert group consists of professors, senior engineers and senior researchers from universities and scientific research institutions, among others. This group expresses their opinions on projects based on professional knowledge, references and experimental results. Based on the information provided by the expert team, the government department can make decisions on whether the documents should be revised, approved or rejected (interview with government officer, 2010).

Evaluated by the guidelines presented in Table S1, government and expert consultation is a well-organized participation process. All of the participants are aware of what they are discussing. Government representatives and experts are involved early in the project plan draft phase and have a chance to provide their opinions for decision-making. Government leadership insures that the expert participation process is not biased in favor of the project owner or any other market player by maintaining a neutral position. But the lack of transparency could cause a barrier between government and the stakeholders who are not represented, especially local citizens.

Evaluated by the guidelines provided in Table S1, LSCs involving local residents were transparent, with a well-explained introduction to the project. Nevertheless, independence and early involvement were lacking. The CDM stakeholders only participated in the last two surveys. They entered the project too late, after the project design was already finished, making it 
impossible to influence decision-making. For the PDD LSC, participants' lists were most likely provided by the project owner or project developer (interview with private project owner and public project developer, 2010), meaning that the project owner could choose local residents who were less critical. In addition, these surveys were conducted by the project developer, raising the possibility that participants might not have felt free to express their opinions. Since snowball sampling method was used to identify stakeholders, a stakeholder introduced by another stakeholder might share similar characteristics or opinions. This is a limitation of this study and should be noted when reading the result.

\section{Discussion}

This case study demonstrates how a host country's own national regulations, laws, and culturally appropriate ways of conducting LSC can take precedence over international CDM rules following the principle of Parties' sovereign rights. The preference for expert consultations over the early involvement of local residents, the absence of active civil society organizations, and the lack of operational and procedural details in public participation for CDM projects are examples of national practice for how the LSC rules are implemented in China. In the context of proposals for improved international regulation on LSC (CDM EB, 2012), this case indicates a number of general issues to be addressed to strengthen national public participation in the future CDM and other mitigation mechanisms. These issues include the need to:

- Define the scope of the LSC process in relation to national rules;

- Define minimum requirements for which stakeholders must be consulted, and for the support of civil society participation;

- Specify the means of participation, when and how consultations take place, and how to take the result into decision-making;

- Explore synergies with other mitigation mechanisms to establish a grievance mechanism for conflict resolution applicable to CDM projects.

\section{Define the scope of the LSC process in relation to national rules}

This case study shows that according to China's national policies, stakeholder consultations were conducted several times as part of EIA requirements before CDM LSC was conducted. From the PDD analysis we noticed that some issues (e.g. noise, water, and air pollutions, etc.) are replicated across the CDM LSC and the national (EIA) LSCs. This indicates that there is a 
strong need to integrate climate governance LSC into local and national policies to avoid duplicating efforts, to save costs, and to provide a consistent framework for stakeholder participation. Therefore, while the international rules for climate mechanisms should provide clear guidance and requirements, they also need to provide flexibility to accommodate local customs and policies. In the case of China the priority is given to expert opinions, which will limit the role of LSC. If the local stakeholders do not have a consensus with the expert opinions, the international rules should give guidelines on how to solve such issues. This has been proposed to EB recently (CDM EB 2015).

\section{Define minimum requirements for which stakeholders to consult}

The project owner/developer provides the list of stakeholders to be consulted. This constitutes a risk that only stakeholders who are positive towards the CDM project will be consulted. The Liyutang hydropower project is a non-controversial case, where only one resident had a negative complaint about noise, which the EIA would take into consideration. However, in controversial projects where conflicts exist between the project owner/developer and local residents, a common problem is that not all the affected stakeholders are consulted. Strengthened LSC rules to define the minimum group of stakeholders to be consulted would ensure a neutral starting point including all potentially affected members of the public, local authorities, a DNA representative, and representatives of local civil society (CDM EB, 2012). As few NGOs are active in Chinese public life, a mandatory requirement to consult a local civil society organization is a challenge. However, the self-organization of citizens as a community-based stakeholder to deliberate with other stakeholders could raise their power in decision-making and represent their concerns better than surveys of individual citizens. To empower civil society, awareness-raising is needed to frame citizens as knowledgeable about local impacts, and capable of full participation. This point has been emphasized in REDD+ guidelines, but should also be followed in other climate mechanisms.

\section{Specify the means of participation, when and how consultations take place}

Three LSC approaches were used in the case study project: surveys for local residents, comments invitation, and government and expert consultation. The former two were transparent, and most stakeholders participated, including local residents. The last one was carried out behind 
closed doors with limited stakeholder involvement. Most decisions were made during the government and expert consultation, and the local residents were involved at a late stage, with little scope to influence the project design. In $20 \%$ of the 109 projects, stakeholders made negative comments but in only $8 \%$ of the projects the LSC process led to revisions of the PDD based on the comments received. This indicates a need to specify how public opinion should be taken into account. It also reflects the weakness that local stakeholders, and especially CDM stakeholders, are not involved at an early stage. Proposed improvements to the CDM LSC rules have been made to define the start time of the first round of LSCs to be followed up with a second round of LSCs on how the first comments are taken into consideration (CDM EB, 2012). These improvements would ensure a more robust process for LSC but they were not adopted by the EB due to concerns over negative impacts for project developers, including higher transaction costs and reduced flexibility. Further refinement of the proposals was requested and the strengthened rules are now being considered in the process of revising the CDM modalities and procedures. To ensure the implementation of improved LSC rules in both CDM and other climate mechanisms, there is a general need to develop good practice guidance for participation methods. In addition, the starting time of LSC and how stakeholders' comments should be taken into account in decision-making needs to be regulated in the policies with detailed guidelines.

\section{Explore synergies with other mitigation mechanisms to establish a grievance mechanism applicable to CDM projects}

The case study shows that there are no national rules in place to address the need for independent conflict resolution in CDM projects. To ensure that potential negative impacts that occur during project implementation are addressed, a grievance mechanism is needed. Such a mechanism should take into account emerging initiatives for a grievance mechanism for the Green Climate Fund, along with best practices and other established UNFCCC safeguards for REDD+ and the UN-REDD`s Social and Environmental Principles and Criteria. Increased coordination and identification of synergies with other mechanisms is also needed to avoid duplicating efforts.

\section{Conclusions and Recommendations}

The CDM has a number of existing rules on how to conduct and validate LSC. Yet, numerous projects in the past years have come under criticism for disregarding these rules in the 
process and for hampering the social integrity of projects, often leading to disputes and conflict. These are not only caused by vague CDM rules on local stakeholder consultation but are mainly the result of:

- The deliberate choice of participating stakeholders, which are likely to be favorable to the project owner/developer;

- $\quad$ Not building on existing civil society participatory structures;

- $\quad$ Not delivering the promised benefits, or even threatening critical stakeholders;

- The lack of remedy that leaves affected communities without an option to raise concerns once a CDM project is registered.

The experience of the CDM points to the lack of good practice guidance and public participation in the CDM. Considering the type and number of CDM projects that are likely to bring adverse effects for local peoples, it is of key importance to draw on existing experience in employing rules and procedures. To improve the impact of CDM project activities, and for that matter, all climate mitigation activities, best practice guidance on how to implement existing rules is needed. But beyond that, the CDM needs to catch up with policy frameworks of mechanisms that are not based on offsetting but look beyond $\mathrm{CO}_{2}$ reduction to other non-carbon benefits. Creating synergies with other mechanisms, by drawing from their experience and best practices, would inform the development of a strong framework for national and international mitigation mechanisms. This would involve assembling a large network of civil society organizations and project partners, examining various national best practices about LSC and the engagement of local communities in data collection and the monitoring of co-benefits and social safeguards in the CDM, REDD+, and other mitigation mechanisms.

The ongoing CDM reform process offers a crucial opportunity to develop this policy framework, including a robust LSC process throughout the implementation of the CDM project activity, a grievance mechanism to address potential adverse impacts of CDM project activities, and a safeguard system that includes the monitoring of sustainable development benefits. A more precise set of rules, and validation and reporting requirements would in turn allow for greater involvement from local communities and stakeholders. The reform process would abate the shortcomings of the current system, which enables project approval despite a lack of attention to a project's human rights impacts and non-carbon benefits. This will also shade a light on the 
LSC rules in REDD+ and other climate mechanisms, where several improvements on LSC guidelines will be needed, including integrating LSC rules with existing national LSC policies, providing practical LSC implementation guidelines for potential participation mechanisms, and regulating on how to take stakeholders' comments into decision.

A stronger framework would not only facilitate good climate governance and strengthen the legitimacy of CDM projects, but would also attract innovative financing instruments that are based on public trust and acceptance as a key driver for sustainable investments. With the 2015 international climate change agreement under development, increased focus and understanding is thus important to ensure effective participation of civil society in the decision making process at both the international and national levels.

\section{Acknowledgement}

We thank Eva Filzmoser and Urska Trunk from Carbon Market Watch for their contribution to an earlier version of the manuscript. 


\section{References}

Berry J. W., Segall, M. H., \& Kagitchibasi C. (Eds.). (1997). Handbook of Cross-cultural Psychology Volume 3: Social Behavior and Applications, 2nd edition. Massachusetts: Allyn \& Bacon

Buckley, 1. (2007). Hydropower in China: public participation \& energy diversity key. Retrieved from: http://www.renewableenergyworld.com/rea/news/article/2007/05/hydropower-in-chinapublic-participation-energy-diversity-key-48332

Carbon Market Watch. (2014). Improving the Stakeholder Consultation Processes. Presentation by Eva Filzmoser at Africa Regional Workshop, 30 June - 1 July, Windhoek, Namibia, Plenary 4: Enhancement of participation of local stakeholders, key to success of CDM projects.

CDM EB. (2011a). Call for inputs on the validation process. Retrieved from: https://cdm.unfccc.int/public_inputs/2011/eb62_02/index.html

CDM EB. (2011b). CDM validation and verification standard. Retrieved from: https://cdm.unfccc.int/Reference/Standards/accr_stan02.pdf

CDM EB. (2012). Annex 22 in EB meeting No. 069. Retrived from: http://cdm.unfccc.int/Meetings/MeetingInfo/DB/IGK8TFBJA59UWDX/view

CDM EB. (2015). CDM-EB84-AA-A14, concept note: improvigin stakeholder consultation processes. $\quad$ Retrieved from: https://cdm.unfccc.int/filestorage/N/8/9/N894CMVT5JZP03HDGWORBIYLAXU16S/eb84_pro pan14.pdf?t=MHp8bm9qb3VqfDAh45NXEDEr9jGhiMH9ZfzD

Ecosecurity Inc. (2008). Project design documentation of Liyutang small scale hydropower project. Retrived from https://cdm.unfccc.int/

FCP, Forest Carbon Partnership. (2011). Forest Carbon Partnership Facility (FCPF) Readiness Fund Common approach to environmental and social safeguards for multiple delivery partners. Retrieved from: http://www.forestcarbonpartnership.org/sites/forestcarbonpartnership.org/files/Documents/PDF/ Nov2011/FCPF\%20Readiness\%20Fund\%20Common\%20Approach\%20_Final_\%2010-Aug2011_Revised.pdf

FCP, Forest Carbon Partnership. (2012). Guidelines on stakeholder engagement in REDD+ Readiness with a focus on the participation of indigenous peoples and other forest- dependent communities. Retrieved

from: http://www.unredd.net/index.php?option=com_docman\&task=doc_download\&gid=6862\&Itemi $\mathrm{d}=53$

GCF, Green Climate Fund. (2014a). Guiding framework and procedures for accrediting national, regional and international implementing entities and intermediaries, including the fund's 
fiduciary principles and standards and environmental and social safeguards. Meeting of the Board, GCF/B.07/02, 7 May 2014.

GCF, Green Climate Fund (2014b). Initial results management framework of the fund. Meeting of the Board, GCF/B.07/04, 7 May 2014

Government of the PRC (People's Republic of China). (2005). Measures for operation and management of Clean Development Mechanism Projects in China. Retrieved from: https://cdm.unfccc.int/filestorage/Z/7/2/Z728YJVOCUMFX6SKEA4DQ9RWHBG05T/Measure s\%20for\%20CDM\%20Projects.pdf?t=TXN8bmw5NnBqfDBtpA7x6wtD5ecuQza8C_yY

Government of the PRC (People's Republic of China). (2006). 环保总局发布《环境影响评价 公众参与暂时行办法》 [Ministry of environmental protection of the People's Republic of China issue 'Provisional measure of Environmental impact assessment public participation']. Webpage in Chinese, retrieved from http://202.123.110.5/jrzg/2006-02/22/content_207093_2.htm

Gu, L., \& Sheate, W. R. (2005). Institutional challenges for EIA implementation in China: a case study of development versus environmental protection. Environmental management, 36, 125142. doi: 10.1007/s00267-003-0127-x

Hong, Y., \& Luan, S. (1999). Public participation in Chinese EIAs. Chongqing Environ. Sci., 21, 28-30

Johl, A., \& Lador, Y. (2012). A Human Rights-based Approach to Climate Finance. Friderich Ebert Stiftung. Retrieved from: http://library.fes.de/pdf-files/iez/global/08933.pdf

Lamers, M., Ottow, B., Francois, G., Vonkorff, Y. (2010). Beyond dry feet? Experiences from a participatory water management planning case in the Netherlands. Ecol. Soc., 15(1): 14.

Li, L., Feng J., Wang M., Wu Y. Zhang Gu. Zou H. (Eds.). (2008). The China legal Development Yearbook, Volume 1: On the Development of Rule of Law in China. Leiden: Koninklijke Brill NV \& Beijing: Social Sciences Academic Press.

Lieberthal, K. \& Lampton, D. M. (Eds.). (1992). Bureaucracy, Politics, and Decision Making in Post-Mao China. Berkeley, Los Angeles, Oxford: University of California Press.

Martinsons, M. \& Davison, R. M. (2007). Strategic decision making and support systems: Comparing American, Japanese and Chinese management. Decis. Support Syst., 32, 284-300

MEPPRC (Ministry of environmental protection of the People's Republic of China). (2008). 建 设项目环境影响评价分类管理名录 [Construction project EIA categorized management catelogue]. Document in Chinese, retrieved http://www.zhb.gov.cn/info/bgw/bl/200809/W020080905398664224537.pdf

Rowe, G., \& Frewer, L. (2000). Public participation methods: A framework for evaluation. Science, technology, and Human values, 25, 3-29. doi: 10.1177/016224390002500101 
Rowe, G., Reynolds, C. Frewer L. (2001). Chapter 24: Public participation in developing policy related to food issues. In Frewer, L., Risvik E., \& Schifferstein H. (Eds.), Food, People and Society: A European Perspective of Consumers' Food Choices (pp. 415-432). New York: Springer-Verlag Berlin Heidelberg.

Schade, J., \& Obergassel, W. (2014). Human rights and the Clean Development Mechanism. Cambridge Review of International Affairs, 27, 717-735. doi: 10.1080/09557571.2014.961407

Theguardian. (2014). 'Green' dam linked to killings of six indigenous people in Guatemala. Retried from: http://www.theguardian.com/environment/2015/mar/26/santa-rita-green-damkillings-indigenous-people-guatemala

UNFCCC (United Nation Framework Convention on Climate Change). (1992). Article 6: Education, training and public awareness. Retrieved from: http://unfccc.int/essential_background/convention/background/items/1366.php\

UNFCCC (United Nation Framework Convention on Climate Change). (2013). Decision 3: guidance relating to the clean development mechanism. In: Report of the conference of the parties serving as the meeting of the parties to the Kyoto Protocol on its ninth session, held in Warsaw from 11 to 23 November 2013. Retrieved from: http://unfccc.int/resource/docs/2013/cmp9/eng/09a01.pdf

Zorrilla, P., Carmona, G., De la Hera, A., Varela-Ortega, C., Martinez-Santos, P., Bromley, J., Henriksen, J. (2009). Evaluation of Bayesian networks as a tool for participatory water resources management: Application to the Upper Guadiana basin in Spain. Ecol. Soc., 15(3): 12. 
Table 1: Evaluation Results of Stakeholder Participation in Small-Scale Hydropower CDM Projects

\begin{tabular}{|c|c|c|}
\hline Guideline & Indicator & $\begin{array}{l}\text { Percentage of PDDs coded } \\
\text { with corresponding } \\
\text { indicator }\end{array}$ \\
\hline $\begin{array}{l}\text { Stakeholder } \\
\text { Representative }\end{array}$ & $\begin{array}{l}\text { Stakeholders } 1 \text { are chosen } \\
\text { representatively } \\
\text { according to age, } \\
\text { education level, occupation, gender } \\
\text { and nation. }\end{array}$ & $80 \%$ \\
\hline \multirow{4}{*}{$\begin{array}{l}\text { What mechanism } \\
\text { is used to get } \\
\text { stakeholders } \\
\text { involved? }\end{array}$} & Survey & $93 \%$ \\
\hline & Consultation meeting & $40 \%$ \\
\hline & Invitation for comments & $16.5 \%$ \\
\hline & Government and expert consultation & $6.4 \%$ \\
\hline $\begin{array}{l}\text { Task definition: Is } \\
\text { the nature and }\end{array}$ & $\begin{array}{l}\text { Project description and discussion } \\
\text { issue are defined and explained. }\end{array}$ & $90 \%$ \\
\hline $\begin{array}{l}\text { scope } \\
\text { participation task } \\
\text { defined and } \\
\text { explained to the } \\
\text { stakeholders? }\end{array}$ & $\begin{array}{l}\text { Public participation mechanism is } \\
\text { defined and explained. }\end{array}$ & $53 \%$ \\
\hline Early involvement & $\begin{array}{l}\text { Stakeholders are involved before the } \\
\text { first draft is done. }\end{array}$ & $0 \%$ \\
\hline Independence & $\begin{array}{l}\text { Stakeholder participation is } \\
\text { conducted by an independent third- } \\
\text { party }\end{array}$ & $9 \%$ \\
\hline Transparency & $\begin{array}{l}\text { Stakeholder participation invitation is } \\
\text { published. }\end{array}$ & $40 \%$ \\
\hline
\end{tabular}




\begin{tabular}{|l|l|l|}
\hline & $\begin{array}{l}\text { Stakeholder participation process is } \\
\text { transparent. }\end{array}$ & $1 \%$ \\
\cline { 2 - 3 } & $\begin{array}{l}\text { Stakeholder participation resultsare } \\
\text { published. }\end{array}$ & $0 \%$ \\
\hline Decision making & $\begin{array}{l}\text { Project design is revised according to } \\
\text { the negative comments received in } \\
\text { stakeholder participation process }\end{array}$ & $8 \%$ \\
\hline
\end{tabular}




\section{Appendices}

Table S1: Guidelines for stakeholder participation process analysis

\begin{tabular}{|c|c|c|c|c|}
\hline $\begin{array}{l}\text { Stakeholder } \\
\text { participation } \\
\text { process }\end{array}$ & $\begin{array}{c}\text { Guidelines in } \\
\text { this study }\end{array}$ & Assessment indicators & $\begin{array}{l}\text { Corresponding assessment } \\
\text { criteria in Rowe and Fewer } \\
(2000)\end{array}$ & Delimitation \\
\hline \multirow[t]{2}{*}{ Stakeholders } & $\begin{array}{l}\text { Who are } \\
\text { considered as } \\
\text { stakeholders? }\end{array}$ & $\begin{array}{l}\text { 1. Local resident; } \\
\text { 2. Local government; } \\
\text { 3. Related bank; } \\
\text { 4. Related power } \\
\text { company; } \\
\text { 5. Social organization; } \\
\text { 6. Related enterprise; } \\
\text { 7. Expert }\end{array}$ & & $\begin{array}{l}\text { NGOs are recorded as social } \\
\text { organization. Related enterprise } \\
\text { does not include bank, power } \\
\text { company, project owner and social } \\
\text { organizations. }\end{array}$ \\
\hline & $\begin{array}{l}\text { Are they } \\
\text { representative? }\end{array}$ & $\begin{array}{l}\text { It is assessed by the } \\
\text { variation of following } \\
\text { participant attributes: } \\
\text { 1. Age; } \\
\text { 2. Education level; } \\
\text { 3. Occupation; } \\
\text { 4. Gender; } \\
\text { 5. Nation. }\end{array}$ & $\begin{array}{l}\text { Criterion of representativeness: } \\
\text { The public participants should } \\
\text { comprise a broadly } \\
\text { representative sample of the } \\
\text { population of the affected } \\
\text { public. }\end{array}$ & \\
\hline
\end{tabular}




\begin{tabular}{|c|c|c|c|c|}
\hline $\begin{array}{l}\text { Participatory } \\
\text { approach }\end{array}$ & $\begin{array}{l}\text { What method is } \\
\text { used to involve } \\
\text { stakeholders? }\end{array}$ & $\begin{array}{l}\text { 1. Survey; } \\
\text { 2. Government or expert } \\
\text { consultation; } \\
\text { 3. Consultation meeting; } \\
\text { 4. Comments invitation }\end{array}$ & $\begin{array}{l}\text { Criterion of structured decision } \\
\text { making: The participation } \\
\text { exercise should use/provide } \\
\text { appropriate mechanisms for } \\
\text { structuring and displaying the } \\
\text { decision-making process. } \\
\text { Criterion of cost-effectiveness: } \\
\text { The procedure should in some } \\
\text { sense be cost-effective. } \\
\text { - We analyzed each of the } \\
\text { participatory approach and } \\
\text { provided answers to the } \\
\text { original two criteria, together } \\
\text { with other strength and } \\
\text { weaknesses (see section 4.3) }\end{array}$ & $\begin{array}{l}\text { Visiting or interview which is } \\
\text { recorded in questionnaires is } \\
\text { considered as survey. The } \\
\text { questionnaires are in paper forms } \\
\text { and should be handed to related } \\
\text { stakeholders in person. } \\
\text { Consultation meeting, meeting } \\
\text { (without explanation), public } \\
\text { meeting and symposium are all } \\
\text { considered as consultation meeting. } \\
\text { These meetings should take place at } \\
\text { an appropriate place where a large } \\
\text { amount of affected population can } \\
\text { be reached. } \\
\text { Comments invitation means publish } \\
\text { project information and invite for } \\
\text { public's comments via E-mail, } \\
\text { phone, letter, etc. }\end{array}$ \\
\hline & $\begin{array}{l}\text { Task definition: } \\
\text { Is the nature and } \\
\text { scope of }\end{array}$ & $\begin{array}{l}\text { Whether the following } \\
\text { three components are } \\
\text { defined and introduced to }\end{array}$ & $\begin{array}{l}\text { Criterion of task definition: The } \\
\text { nature and scope of the } \\
\text { participation task should be } \\
\text { clearly defined. }\end{array}$ & $\begin{array}{l}\text { If a survey is conducted, public } \\
\text { participation mechanism and } \\
\text { discussion issue are considered as }\end{array}$ \\
\hline
\end{tabular}




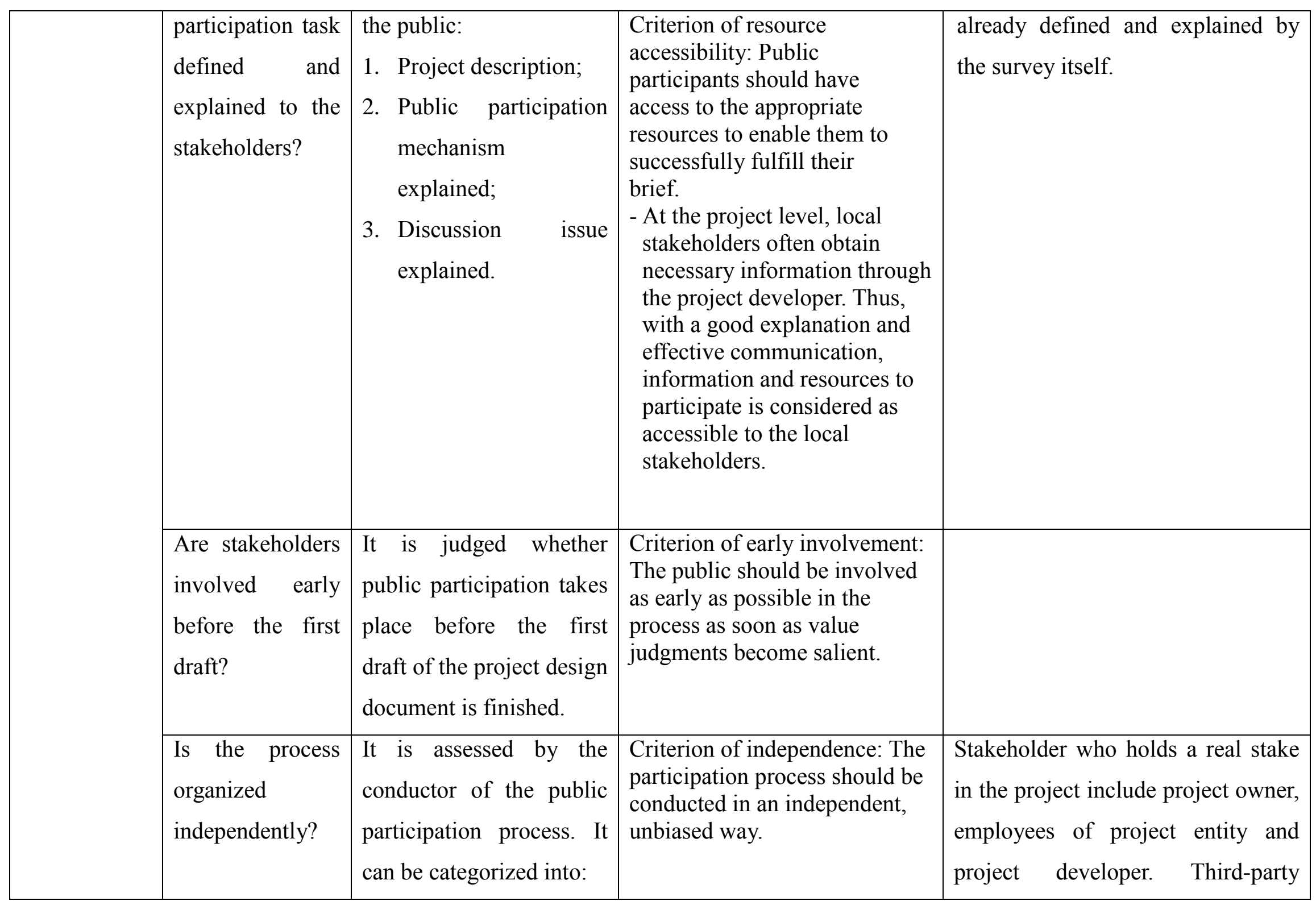




\begin{tabular}{|c|c|c|c|c|}
\hline & & $\begin{array}{l}\text { 1. Stakeholder who } \\
\text { holds a real stake in } \\
\text { the project; } \\
\text { 2. Neutral third-party }\end{array}$ & & $\begin{array}{l}\text { includes EIA institution, } \\
\text { government, NGOs, DOE and other } \\
\text { unspecified third-parties. }\end{array}$ \\
\hline & $\begin{array}{l}\text { Is the process } \\
\text { transparent? }\end{array}$ & $\begin{array}{l}\text { Transparency in the } \\
\text { following } 3 \text { categorizes } \\
\text { will be assessed: } \\
\text { 1. Invitation published; } \\
\text { 2. Participation process } \\
\text { transparency; } \\
\text { 3. Result publish }\end{array}$ & $\begin{array}{l}\text { Criterion of transparency: The } \\
\text { process should be transparent } \\
\text { so that the public can see what } \\
\text { is going on and how decisions } \\
\text { are being made. }\end{array}$ & $\begin{array}{l}\text { Invitation publish includes publish } \\
\text { of survey, consultation or meeting } \\
\text { time, place, topics. etc. online or at } \\
\text { visible sites. } \\
\text { Result published means that the } \\
\text { result of the consultation is } \\
\text { available online or at visible sites. }\end{array}$ \\
\hline $\begin{array}{l}\text { Decision- } \\
\text { making }\end{array}$ & $\begin{array}{l}\text { How are } \\
\text { stakeholders' } \\
\text { views } \\
\text { incorporated into } \\
\text { decisions }\end{array}$ & $\begin{array}{l}\text { It is assessed by whether } \\
\text { the project design is } \\
\text { revised according to } \\
\text { public's comments. }\end{array}$ & $\begin{array}{l}\text { Criterion of influence: The } \\
\text { output of the procedure should } \\
\text { have a genuine } \\
\text { impact on policy. }\end{array}$ & $\begin{array}{l}\text { Public's view is considered as } \\
\text { taking into decision only if negative } \\
\text { comments from public are received, } \\
\text { and accordingly solutions are taken } \\
\text { into project plan by the project } \\
\text { owner. }\end{array}$ \\
\hline
\end{tabular}


Table S2: Interviews list

\begin{tabular}{|c|c|c|c|c|}
\hline $\begin{array}{l}\text { Interview } \\
\text { Number }\end{array}$ & Date & Place & Interviewee institutional belonging & $\begin{array}{l}\text { Direct or indirect } \\
\text { stakeholder }\end{array}$ \\
\hline 1. & Mar. 2010 & Chongqing & Private hydropower project owner & Indirect \\
\hline \multirow[t]{2}{*}{2.} & \multirow[t]{2}{*}{ Mar. 2010} & \multirow[t]{2}{*}{ Chongqing } & Province government officer; & Direct \\
\hline & & & Public project developer; & Indirect \\
\hline 3. & Mar. 2010 & Chongqing & Academic environmental expert & Indirect \\
\hline 4. & Apr. 2010 & Chongqing & $\begin{array}{l}\text { Local residents, belonging to } 4 \\
\text { different families. There is only one } \\
\text { mid-aged resident. The rest are elder } \\
\text { people. }\end{array}$ & Direct \\
\hline 5. & Apr. 2010 & Beijing & PDD consultant & Indirect \\
\hline 6. & Apr. 2010 & Beijing & CER buyer \& PDD consultant & Direct \\
\hline 7. & Apr. 2010 & Beijing & DOE & Direct \\
\hline 8. & Apr. 2010 & Beijing & Golden standard & Indirect \\
\hline 9. & Apr. 2010 & Beijing & NGO & Indirect \\
\hline 10. & Apr. 2010 & E-mail & China's DNA board & Direct \\
\hline 11. & May.2010 & E-mail & EB & Direct \\
\hline
\end{tabular}

